\title{
A SURGE OF BUALTAR GLACIER, KARAKORAM RANGE, PAKISTAN: A POSSIBLE LANDSLIDE TRIGGER
}

\author{
By James S. GARDNER \\ (Department of Geography, University of Waterloo, Waterloo, Ontario N2L 3G1, Canada) \\ and Kenneth HewitT \\ (Department of Geography, Wilfrid Laurier University, Waterloo, Ontario N2L 3G5, Canada)
}

\begin{abstract}
Bualtar Glacier, Karakoram Range, northern Pakistan, surged during the spring and early summer of 1987. This followed a major episode of three landslides which impacted part of the glacier ablation zone on 30-31 July 1986. In May 1987, surface velocities of $7 \mathrm{~m} \mathrm{~d}^{-1}$ were measured at one profile down-glacier from the landslide deposits, where in 1986 velocities were an order of magnitude less. Surface and hydrological characteristics of the glacier in and down-glacier from the landslide deposit were also indicative of surge-like behavior in 1987, and a return to pre-surge conditions by 1988 .
\end{abstract}

\section{INTRODUCTION}

An order-of-magnitude increase in glacier-surface velocities over those of the previous year was measured in May 1987 on Bualtar Glacier in the Karakoram Range of northern Pakistan. The increased velocities were noted in an area down-glacier from the impact zone of three major landslides which occurred in July 1986 (Hewitt, 1988). The purpose of this paper is to describe the surge behavior and the recovery from it, and to outline the coincidence in time and space of the surge and the landslide event and deposits.

Increasing field evidence suggests that high-magnitude landslides are not uncommon in glaciated mountain areas (Cruden, 1976; Porter and Orombelli, 1981; Whitehouse, 1983; Johnson, 1984). Some research suggests relationships between the glaciation/deglaciation process and slope failures (Whalley, 1974; Evans and Clague, 1988). Cases such as the Sherman Glacier rockslide of 1964 (Shreve, 1966), the Tahoma rockfall on Mount Rainier (Crandell and Fahnestock, 1965), the Sioux Glacier rock avalanche (Reid, 1969), the South Georgia rockslide (Gordon and others, 1978 ), and the Brenva Glacier rockfall in 1920 (Porter and Orombelli, 1981) have permitted some consideration of the impacts of large slope failures on glacier systems. The Bualtar Glacier case, described in this paper, provides a further opportunity to examine some of these relationships.

Bualtar Glacier is a medium-sized glacier flowing off the northern slope of the Lesser Karakoram in the Nagir district (Fig. 1). It was one of several glaciers chosen for detailed study by the Snow and Ice Hydrology Project, a joint Pakistan-Canada project directed at assessment of the snow and ice sources of the Indus River. Bualtar Glacier was first visited by project members in 1985, while some detailed ablation, velocity, and geomorphological work was carried out in 1986, providing part of the data base for this report. The glacier was visited again in 1987 and briefly in 1988. Approximately $20 \mathrm{~km}$ in length, Bualtar Glacier covers $84 \mathrm{~km}^{2}$ between the elevations of 7250 and $2440 \mathrm{~m}$. The equilibrium-line elevation is approximately $4270 \mathrm{~m}$ and the accumulation area ratio is 0.70 . Bualtar Glacier may be prone to surge behavior. Many Karakoram glaciers, especially those in the Hunza-Nagir district where Bualtar Glacier is located, have surged (Hewitt, 1969). There is evidence that the Bualtar Glacier terminus has advanced to block the Hispar River within this century. However, there is no evidence that this involved a surge. Also, local inhabitants indicated that the 1987 behavior of Bualtar Glacier was unusual in their experiences.

The 1986 landslides produced deposits covering approximately $4 \mathrm{~km}^{2}$ of the glacier surface, $10 \mathrm{~km}$ from the terminus (Fig. 1). The physical properties of the three landslides and their deposits have been described by Hewitt (1988). The resulting deposits contained approximately $20 \times 10^{6} \mathrm{~m}^{3}$ of material, ranged in thickness from 2 to $10 \mathrm{~m}$ (average $5 \mathrm{~m}$ ), and completely masked the existing glacier-surface topography (Fig. 2). The changing positions of the deposit margins in the subsequent 2 years provided important clues about the underlying glacier motion.

\section{THE GLACIER SURGE}

The data and information describing the Bualtar Glacier surge come from several sources. These include observations and comments of people living in the nearby villages of Hopar, limited before and after measurements of glaciersurface velocities, before and after photography of the glacier and landslide deposit areas, and field observations and mapping in 1986, 1987, and 1988.

Changes in Bualtar Glacier were first noticed by Hopar people in mid-winter 1987. They remarked that increased crevassing, especially along the glacier margins, was evident between Bualtar and Hopar (Fig. 1) in January 1987. These people are sensitive to changes in the glacier surface given that they cross the glacier regularly for access to pastures, villages, and firewood supplies. By May 1987, glacier crossings with animals in the vicinity of Hopar became impossible as a result of crevassing and ice thickening along the glacier margins. The annual movement of animals to summer high pastures required an alternative and longer route which circumvented Bualtar Glacier. By August 1987, regular glacier crossings with animals at Hopar were again taking place. These continued in 1988.

These observations by, and impacts on, the local people are supported by our survey and other data. Survey results from a cross-glacier, six-stake profile at Hopar/Shishkin in 1986 (15 July-3 August) produced a mean surface velocity of $0.40 \mathrm{~m} \mathrm{~d}^{-1}$ (Fig. 1). This surface velocity is in general agreement with "normal" summer velocities for other glaciers in the region (Snow and Ice Hydrology Project, 1987). Based on six stakes, the May 1987 surface velocities at the Hopar/Shishkin profile averaged $7.59 \mathrm{~m} \mathrm{~d}^{-1}$ (Fig. 1). The Hopar profile could not be maintained through the summer of 1987 due to difficult access and rapid changes in the glacier surface which disrupted the survey stakes. In August 1988, a survey of a six-stake profile over a $7 \mathrm{~d}$ period was attempted at the Hopar-Shiskin profile. At the end of the period, only two stakes remained in place on the glacier surface, both at the ice margins. The others were probably removed by locals during their daily cross-glacier travels. Although based on a small sample over a short period, these 

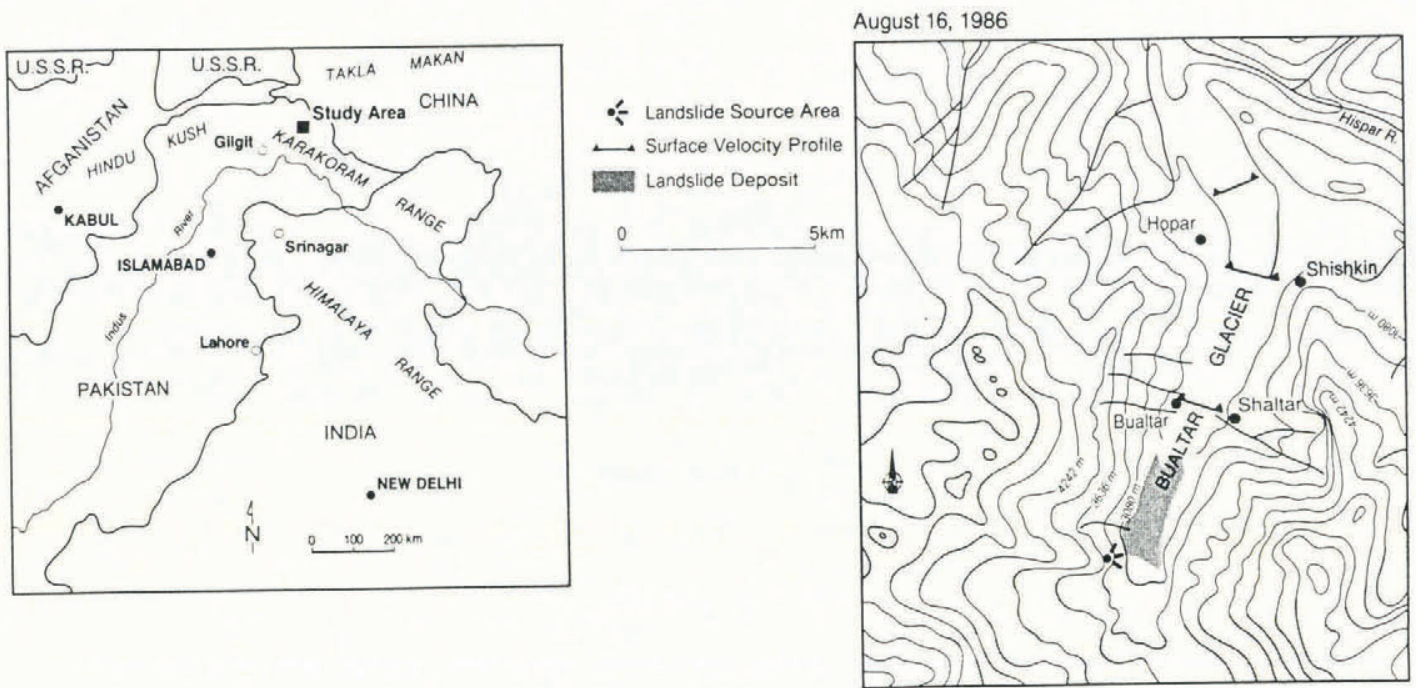

GLACIER SURFACE VELOCITIES

(A) On Basis of Mapped Area of Deposit Deposit leading edge:

Aug. $16 / 86-$ May $26 / 87=5.9 \mathrm{md}^{-1}$ May $26 / 87$ - July $9 / 88=1.80 \mathrm{md}^{-1}$ Deposit trailing edge:

Aug. $16 / 86-$ May $26 / 87=1.54 \mathrm{md}^{-1}$ May $26 / 87$ - July $9 / 88=3.30 \mathrm{md}^{-1}$

(B) On Basis of Stake Profiles

Hopar/Shishkin Profile

July 15 - Aug. $3 / 86=0.40 \mathrm{md}^{-1}$

May $13-$ May $31 / 87=7.59 \mathrm{md}^{-1}$

Aug. 19 - Aug. $26 / 88=0.27 \mathrm{md}^{-1}$

Bualtar/Shaltar Profile

June 1 - June $3 / 87=3.11 \mathrm{md}^{-1}$

June 3 - July $4 / 87=2.12 \mathrm{md}^{-1}$

July 4 - Aug. $18 / 87=0.62 \mathrm{md}^{-1}$
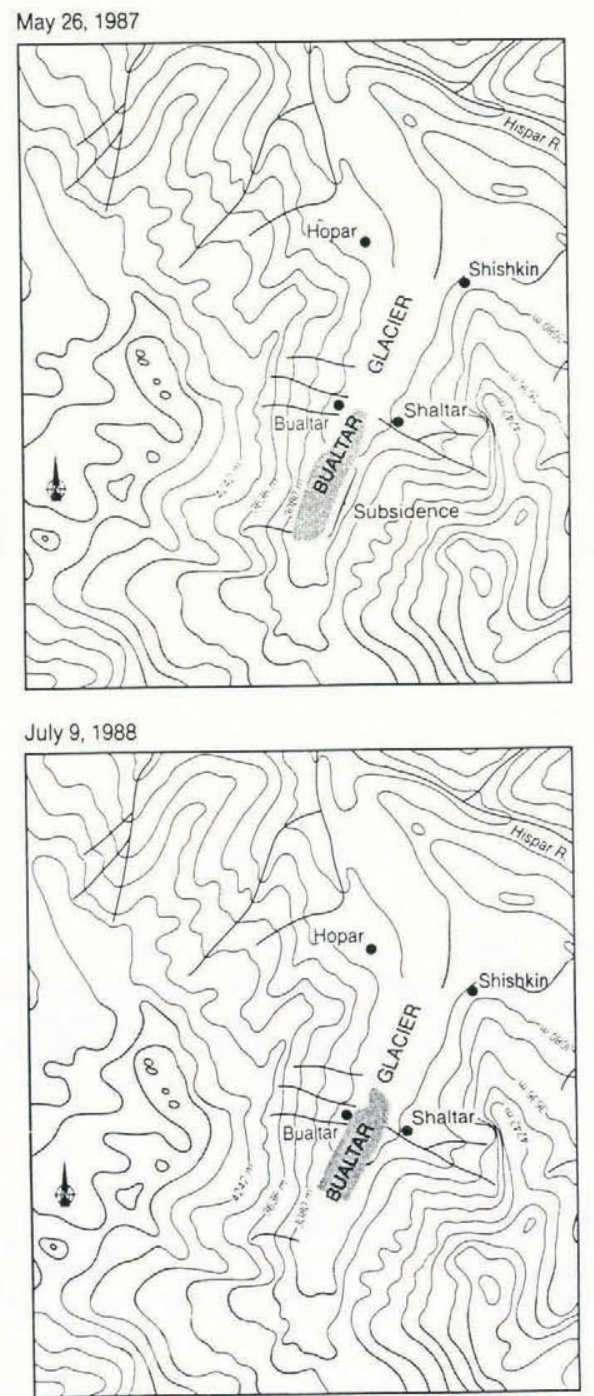

Fig. 1. The study area location and the movement of the Bualtar Glacier landslide deposit in the period August 1986-July 1988. Glacier-surface velocities, inferred from the movement of the deposit, are given as are those derived from surveys of stake profiles.

data indicate velocities in the order of $0.27 \mathrm{~m} \mathrm{~d}^{-1}$, well below the high velocities recorded in 1987.

Up-glacier in the landslide deposit area (BualtarShaltar) (Figs 1 and 2), a cross-glacier profile using seven large, prominent rocks was established on 1 June 1987. Re-surveys were made on 3 June, 4 July, and 19 August (Fig. 1), showing initially high velocities followed by a decline in velocity through the summer of 1987.
Before and after photography, field observations, and mapping of the landslide deposit area in 1986, 1987, and 1988 provide further descriptors of glacier behavior. Figure 1 depicts the positions of the landslide deposit in August 1986, May 1987, and July 1988 as reconstructed from field maps and photographs. The sequential maps show not only a down-glacier movement of the deposit area but a change in shape as well. Ice near the leading, or 


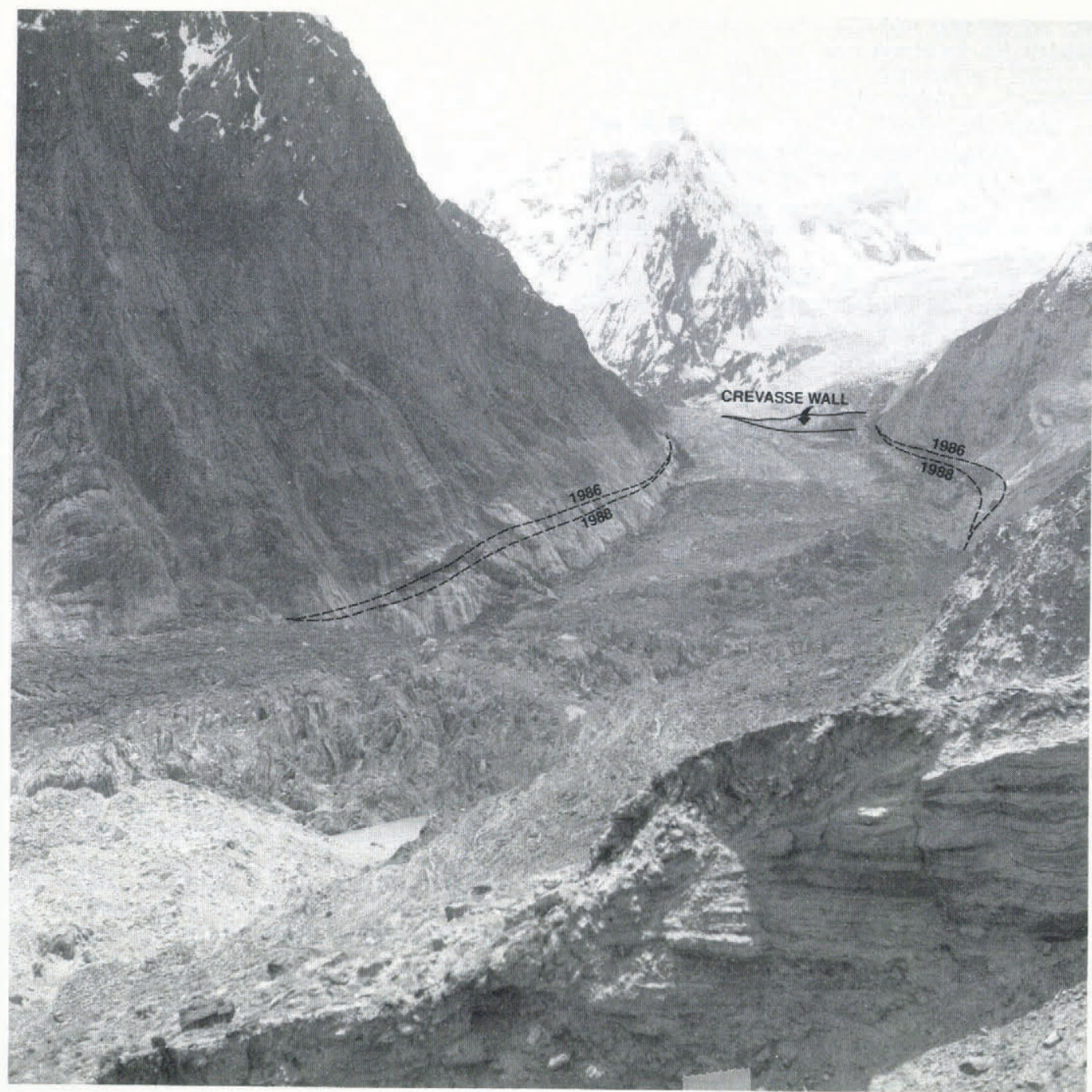

Fig. 2. Bualtar Glacier in the landslide-deposit area in June 1987. Shown in the photograph are the July 1986 and July 1988 levels of the glacier in this area. By June 1987, glacier-surface subsidence of up to $60 \mathrm{~m}$ and extending up-glacier about $3 \mathrm{~km}$ had occurred. Also shown is the hanging wall of a large, vertically displaced crevasse that developed up-glacier from the subsidence area. By July 1988, the level of the glacier surface in the Bualtar area had returned almost to the 1986 level.

down-glacier, edge of the landslide deposit moved four times faster than ice near the trailing, or up-glacier, edge of the landslide deposit in the 10 months following the landslides (Fig. 1). In the following 13 months, this pattern was reversed with ice near the trailing edge moving twice as fast as that near the leading edge (Fig. 1).

Such flow patterns should translate into changes in glacier-surface topography. While we have no longitudinal survey data to illustrate topographic changes, qualitative observations indicate that glacier thickening and lateral expansion down-glacier from Bualtar (Fig. 1) and thinning directly up-glacier from Bualtar occurred in 1987. Down-glacier, the margin expanded into areas which were not occupied by ice in 1986, inundating well-established ice-marginal vegetative communities. Part of this expansion consisted of toppling ice towers from the heavily crevassed glacier margins, as far as $8 \mathrm{~km}$ down-glacier from Bualtar. Slickensided and grooved marginal ice surfaces down-glacier from contacts with the valley wall suggested very active marginal shear and, possibly, increased basal sliding. Other ice-marginal evidence of surge behavior included the development and growth of a number of ice-marginal lakes. In 1987, waters released in the lakes appeared to be of subglacial origin as evidenced by their extremely turbid character (Kamb and others, 1985). During the summer of 1987 at least one of these lakes, that at Hopar, emptied and filled on close to a weekly basis. In 1988, evidence of icemarginal expansion and active marginal shearing had diminished, although most of the ice-marginal lakes remained.
Glacier thinning in 1987 was marked by a subsidence of up to $60 \mathrm{~m}$ up-glacier from Bualtar in the landslidedeposit area (Fig. 2). The subsidence was indicated in 1987 by remnant ice and debris left hanging on the valley wall (Fig. 2) at a level consistent with the 1986 glacier surface. The area of subsidence extended up-glacier a distance of about $3 \mathrm{~km}$. The upper limit of this zone appeared to be indicated by a large cross-glacier crevasse with as much as $30 \mathrm{~m}$ vertical displacement across it (Fig. 2). Before and after photography indicated that this crevasse was not present in July 1986 and, although visible in July 1988, the vertical displacement across it was much reduced. These patterns suggest that the area immediately up-glacier from Bualtar, and coinciding with the landslide deposit, served as the ice reservoir for the surge observed down-glacier. The large crevasse noted above appears to have marked approximately the upper limit of ice evacuation.

A cone-shaped avalanche-snow deposit observed in 1987 on the glacier's left bank, near Bualtar, provided circumstantial evidence about the timing of subsidence and, by inference, the beginning of the surge. The snow cone was a semi-permanent feature and its base was generally coincident with the glacier surface. In June 1987 the cone was doubled, the base of the upper cone coinciding with a higher glacier level and that of the superimposed and lower cone coinciding with the lowered surface. Both avalanche snow cones contained snow from the 1986-87 winter, suggesting subsidence during the $1987 \mathrm{mid}$-winter to early spring period. This is approximately synchronous with the first observations by the local people. The fact of two 
distinctive cones representing the cumulative snow-avalanche activity as opposed to a transitional feature supports an hypothesis of rapid subsidence. Winter surge initiation followed by summer termination has been observed on other surging glaciers (Raymond, 1987). The fact that the Bualtar Glacier surge was consistent with this seasonality, and that the surge apparently commenced about 6 months after the landslides, suggests that the latter were causal only indirectly, with other surge mechanisms and triggers coming into play in the interim.

In July 1988, approximately 12 months following the termination of the surge, the area of subsidence had refilled almost to the pre-surge 1986 levels (Fig. 2). The ice evacuated from the surge reservoir area was being replaced by accelerated flow from up-glacier. This is supported by the surface-velocity data derived by mapping the movement of the landslide-deposit leading and trailing edges (Fig. 1; average May 1987 -July $1988=3.3 \mathrm{~m} \mathrm{~d}^{-1}$ ). The position of the trailing edge during the late summer of 1987, and the relatively low velocities measured at the Bualtar-Shaltar profile in August 1987, suggest that the refilling process did not commence until late 1987 or early 1988, perhaps in nother winter-initiated surge. We have no data to indicate that this produced subsidence immediately up-glacier in the ice-fall area and in the accumulation area above (Fig. 2).

Finally, observations over the three field seasons produced no evidence of significant ice thickening or advance in the terminus area.

\section{CONCLUSION}

A surge occurred on Bualtar Glacier between the winter of 1986-87 and the summer of 1987. While a number of glaciers in this region of the Karakoram Range have surged in the past century, we have no definitive evidence that Bualtar Glacier could be classified amongst such surge-prone glaciers.

The temporal and spatial characteristics of the surge, and those of the large landslides which covered $4 \mathrm{~km}^{2}$ of the glacier surface in July 1986, lead to some speculation about the role of the latter in contributing to the surge. The most significant spatial relationship is the coincidence between the landslide impact and deposit area and the area of the glacier which served as the ice reservoir for the surge. This area displayed glacier-surface subsidence and accelerated flow occurred within and down-glacier from it. The area is fully within the glacier-ablation zone and, in before and after photography, appeared not be undergoing any ice-mass build-up in the pre-surge period; such pre-surge build-up of ice is characteristic of the areas that subside in most other surging glaciers (e.g. Raymond, 1987). Following the surge, the depleted ice mass was replaced, almost to pre-surge levels in 12 months by acclerated flow from up-glacier.

The most significant temporal relationship between the two events is the fact that the surge followed the landslides but only after a period of about 6 months. This suggests that in and of themselves the landslide impact and deposits did not trigger the surge directly as through elevating the basal shear stress to a critical value sufficient for surging to occur through accelerated basal sliding. The seasonal timing of the surge is consistent with that observed on some other surging glaciers (Kamb and others, 1985; Raymond, 1987) where accelerated flow has been related to basal sliding occasioned by melt-water accumulation. Such accumulations may be caused by increased inflow and/or break-downs or disruptions of the subglacial hydrological network (Clark and others, 1984). Thus, the timing and the fact that the Bualtar Glacier surge was accompanied by increased release of basal water and evidence of increased ice-marginal shearing down-glacier from the ice reservoir suggest that similar mechanisms may have contributed to the event. In this case, the role of the landslides could be indirect through a disruption of the subglacial hydrology by causing collapse of parts of the network, infusions of large amounts of sediment causing clogging, and/or alteration of inflow of water to the subglacial network in the deposit area.

\section{ACKNOWLEDGEMENTS}

This research was supported in part by the Snow and Ice Hydrology Project (SIHP), a joint International Development Research Centre (Canada) and Water and Power Development Authority (Pakistan) project, and in part by a Canada Natural Sciences and Engineering Research Council Operating Grant to J.S. Gardner. The assistance of SIHP members: G. Young, K. McDonald, J. Schmock, M. Pemberton, P. Frey, and S. Ahmed is gratefully acknowledged.

\section{REFERENCES}

Clarke, G.K.C., S.G. Collins, and D.E. Thompson. 1984. Flow, thermal structure, and subglacial conditions of a surge-type glacier. Can. J. Earth Sci., 21(2), 232-240.

Crandell, D.R. and R.K. Fahnestock, 1965. Rockfalls and avalanches from Little Tahoma Peak on Mount Rainier, Washington. U.S. Geol. Surv. Bull. 1221-4.

Cruden, D.M. 1976. Major rock slides in the Rockies. Can. Geotech. J., 13(1), 8-20.

Evans, S.G. and J.J. Clague. 1988. Catastrophic rock avalanches in glacial environments. In Bonnard, C., ed. Landslides. Proceedings of the 5th International Symposium on Landslides. Rotterdam, Balkema, 11531158 .

Gordon, J.E., R.V. Birnie, and R. Timmis. 1978. A major rockfall and debris slide on the Lyell Glacier, South Georgia. Arct. Alp. Res., 10(1), 49-60.

Hewitt, K. 1969. Glacier surges of the Karakoram Himalaya (Central Asia). Can. J. Earth Sci., 6(4, Pt. 2), 1009-1018.

Hewitt, K. 1988. Catastrophic landslide deposits in the Karakoram Himalaya. Science, 242, 64-66.

Johnson, P.G. 1984. Rock glacier formation by highmagnitude low frequency slope processes in the southwest Yukon. Ann. Assoc. Am. Geogr., 74, 408-419.

Kamb, B., and 7 others. 1985. Glacier surge mechanism: 1982-83 surge of Variegated Glacier, Alaska. Science, 227(4686), 469-479.

Porter, S.C. and G. Orombelli. 1981. Alpine rockfall hazards. Am. Sci., 69(1), 67-75.

Raymond, C.F. 1987. How do glaciers surge? A review. J. Geophys. Res., 92(B9), 9121-9134.

Reid, J.R. 1969. Effects of a debris slide on "Sioux Glacier", south-central Alaska. J. Glaciol., 8(54), 353-367.

Shreve, R.L. 1966. Sherman landslide, Alaska. Science, 154(3757), 1639-1643.

Snow and Ice Hydrology Project. 1987. Annual report 1986. Waterloo, Ontario, Wilfrid Laurier University. Department of Geography.

Walley, W.B. 1974. The mechanics of high-magnitude, lowfrequency rock failure and its importance in a mountainous area. Reading, Reading University. (Reading Geography Papers 27.)

Whitehouse, I.E. 1983. Distribution of large rock avalanche deposits in the central Southern Alps, New Zealand. N.Z. J. Geol. Geophys., 26(3), 271-279. 